\title{
昇圧化学療法に扮ける制癌剂の 薬動力学に関する研究
}

岡本公彰 ${ }^{* 11}$ 高尾业由子 ${ }^{* 21}$ 藤田 浩 ${ }^{* 31}$

\section{1. はじめに}

固形腫瘍の表層部では十分な血管支配がみられ， 酸素と栄養を供給し, 腫瘍細胞の活発な増殖を支 えているが，中心部へ近づくほど血管支配が少な く，次第に細胞は壞死に陷ることが古くから知ら れている。腫瘍中心部の細胞は hypoxic となり, 放射線に酎性を示し, 制癌剂投与の際は, 腫瘍中 心部と表層部の中間の細胞は制癌剈の十分な浸透 が得られず, 本来制癌凨に感受性を示す癌細胞で さえも即性を示し增殖し続けることが知られてお り,このことは今日の化学療法の隘路のひとつと なっているものと思われる。

1977年鈴木ら ${ }^{1.21}$ は, 制嘫郕の組織到達性の改善 法として, 腫瘍血管は正常組織の血管とは異なり, 昇圧郕に反応する平滑筋組織の構築がきわめて不 完全であるため, 昇圧により血管は受動的に搪張 される点に着目し、これをDDSに応用した。す なわち, Angiotensin II (AT-II) を投与し血圧 を正常の1.5倍上昇させると腫瘍組織の血流是が 選択的に $5 \sim 6$ 倍増加し, 腫㾔組織の血流量の減 少を補うことにより制癌郕と腫瘍細胞との接触の

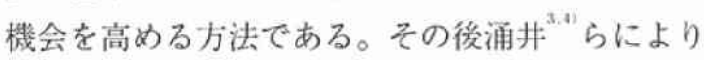
昇圧化学療法 (IHC) として嵒床に用いられ, す でに奏効率の改善, 臨床効果の早期判定が可能で あることなどが多数報告されている ${ }^{3.41}$ 。
われわれは Sarcoma 180 担癌マウスを用い， 5 -fluorouracil ( 5 -FU) 投与後の各種組織内制癌 戍浼度を測定し，IHCにおける薬物動態を詳細に 調へ若干の知見を得たので報告する。

\section{2. 方 法}

ICR 雄性マウス ( 7 週鈴) は日本クレア(林より 購入した。Sarcoma 180 腫瘍は $10^{6}$ 個の細胞を背部 皮下に移植したのち14日目のものを用いた。

平均動脈圧の测定は, Sarcoma 180 担癌マウス に30 $\mathrm{mg} / \mathrm{kg}$ のネンプタール (s. c.) および補助的 にエーテルの吸入による麻醉下で，左㓰動脈より 水銀マノメーターに連結した30Gの注射針を挿入 して観血的に行った。IHCの施行において, 平常 の1.5倍の血圧の上昇が必要とされている。図 1 は 1 - $2 \mu \mathrm{g} / \mathrm{kg} / \mathrm{min} の \mathrm{AT}$ - II 5 分間マウスに 持続投与した際の血圧の変化を示している。その 結果, AT- II $1-2 \mu \mathrm{g} / \mathrm{kg} / \mathrm{min}$ の投与量範囲内 では投与量にかかわりなく, 投与開始 3 分後には 全例目標血压である $150 \pm 5 \%$ に到達し, 安定し て持続した。そこで昇压化学療法の施行に当たっ ては, Sarcoma 180 担癌マウスに血圧測定時と同 じ麻酔方法で, インフュージョンポンプ (Harvard 社製）を用い毎分 $4-8 \mu l$ の速度で 5 分間 AT- II (チバガイギー(株) を尾静脈より投与し ( 1 - $2 \mu \mathrm{g} / \mathrm{kg} / \mathrm{min})$, 血圧を平常の 1.5 倍上䒜さ

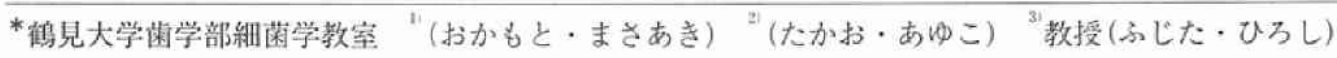




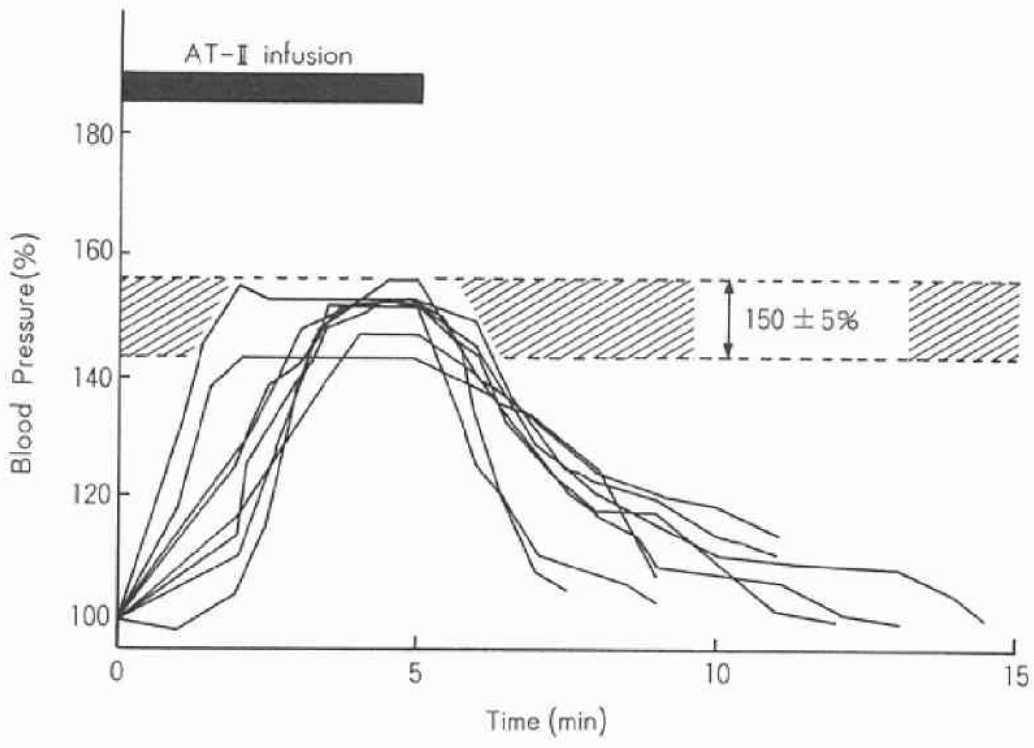

图 1 S.180 担癌マウスに AT-II (1-2 $\mu \mathrm{g} / \mathrm{kg} / \mathrm{min})$ 5 分間投与時の平均動脈圧の変化

せたのち, $40 \mathrm{mg} / \mathrm{kg}$ の 5 -FU を尾静脈より投与 し, さらに10分間 AT-II を持繞投与し血圧を維 持した。制癌剤投与後, 経時的に心荿穿刺により 採血し，潒心分離をし plasma とした。

5 -FU の定显は, 血液は直接に, 組織は生食 で homogenize したのち, 酢酸エチルにて抽出し, S. aureus 209p を用いた bioassay 法により測定し た。

\section{3. 結 果}

\section{1）血中 $5-\mathrm{FU}$ 濃度}

Sarcoma 180 担癌マウスに 5 -FU を投与したの ち5-FUは 2 相性をなし, 血中より速やかに消 失した（図 2 )。5-FU の血中濃度は対照群およ び昇压群において有意の差は認められなかったが, $\mathrm{t} 1 / 2 \beta$, AUCがわずかに增加した。血中の 5 -FU の大部分は胿で代謝され，その分解の効辩 は肝血流量に依存することから，肝血流量は ATー【Iにより影製を受けにくいことを示唆する ものと思われる。

\section{2）各種正常および腫瘍組織内 5-FU の AUC} 各種正常および腫凘組織における5-FU 濃度 を測定し、そのAUCを比較した（図 2, 表 1 )
対照群の各組織の AUC は腫瘍, 肾, 筋肉, 脾, 胃, 肺, 心, 肝, 脎の順に大きかった。AT-II昇 压下では腫瘍組織は対照群と比較し $0.1 \sim 5 \%$ の 危険率で有意に高值を示し, 対照群では 1810 $\mu \mathrm{g} / \mathrm{min} / \mathrm{g}$ あ゙るのに, 昇圧群では2832と1.6倍 に増加した。一方正常組織の AUC は非昇圧群と 比較し何ら䫓著な増加は認められなく, 腫瘍組織 のみに選択的に増加することが明らかとなった。

\section{3）腫瘍重量と腫瘍組織内 $5-F U$ 濃度の関係}

非昇圧群では，5-FU 投与彷10分から4 時間 までの測定期間中, 腫瘍重量が大きくなるに従い,

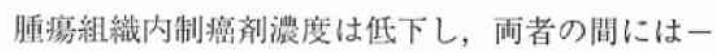
0.946 - 0.386 と強い相関関係がみられた。この ことより大きい腫瘍ほど5-FU は組織内に到達 しにくく, 特に腫瘍中心部には到達しにくいこと が示唆された（図 3 )。

一方, 昇圧群では 5 -FU 投与後10分後には, 腫瘳重量にかかわらず一様に高漂度の 5 -FU が 測定されこのことは腫痹全体に 5 -FU が均等 に分布し, 腫瘍深部にも 5 -FU が到達すること を示唆しているものと思われる。また時間の経過 とともに，小さな腫瘍では大きな腫瘍に比較し， 速やかに対照群の值まで低下しており，腫癔表面 


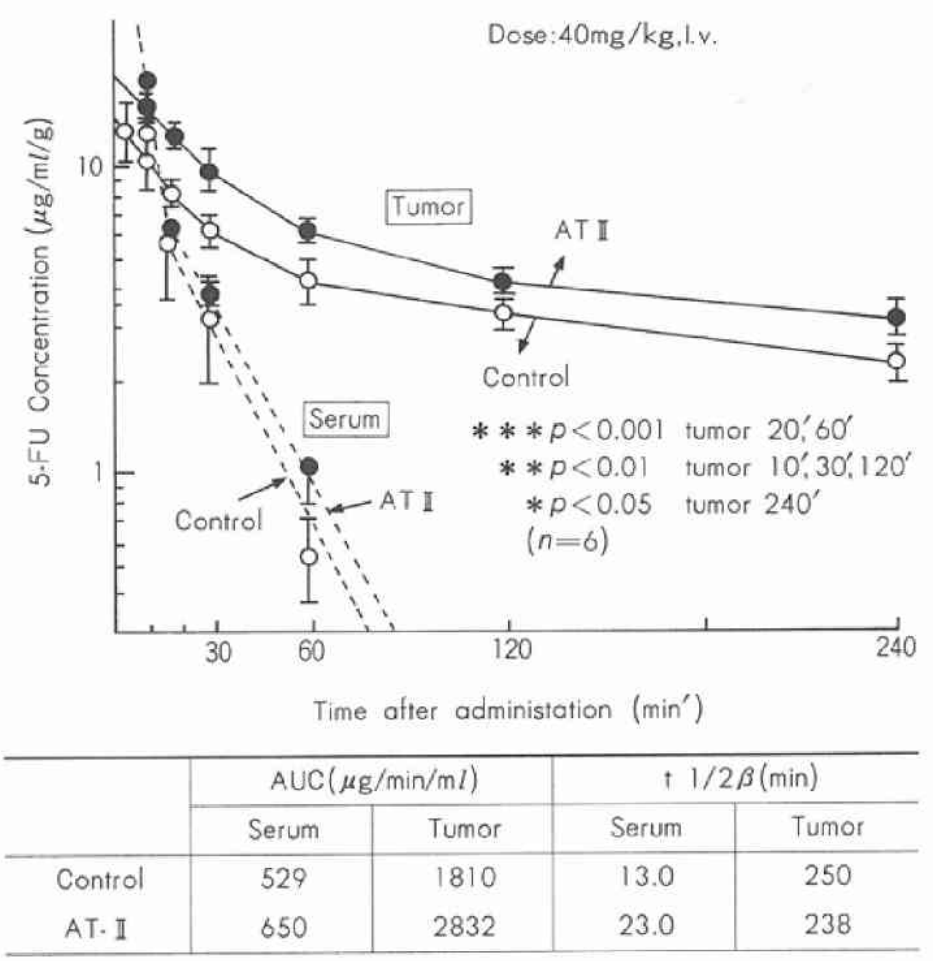

图 2 IHC下におけるS.180 担癌マウスの血中, 腫癌組織内5-FU 濃度とそのAUCおよび半隇期

表 1 IHC下における5-FU 投与後の各種臟 器の AUC

\begin{tabular}{l|c|c|r}
\hline \multirow{2}{*}{} & \multicolumn{2}{|c|}{ AUC $(\mu \mathrm{g} / \mathrm{min} / \mathrm{g})$} & \multicolumn{1}{c}{$\mathrm{T} / \mathrm{C}$} \\
\cline { 2 - 3 } & Control & AT- II & $(\%)$ \\
\hline Brain & 281.2 & 259.1 & 92 \\
Heart & 484.6 & 501.0 & 103 \\
Lung & 615.0 & 637.7 & 104 \\
Liver & 301.0 & 316.4 & 105 \\
Spleen & 823.4 & 767.8 & 93 \\
Kidney & 1788 & 1393 & 78 \\
Stomach & 751.3 & 716.0 & 95 \\
Muscle & 1088 & 1132 & 104 \\
Serum & 529.0 & 650.2 & 123 \\
& & & \\
Tumor & 1810 & 2832 & 156 \\
\hline
\end{tabular}

からの wash out が示唆された。

\section{4）腫瘍重量依存性の 5-FU の AUC の変化}

腫瘍重量と制癌剤濃度の関係式から, 腫瘍重量 別に薬物動態を simulate してみた。その結果,
AUC は腫湟重量に依存して变化した。5-FU 投 与後対照群における0.4gの腫瘍の AUC（0 $240 \mathrm{~min})$ は $1101 \mu \mathrm{g} / \mathrm{min} / \mathrm{g}, 1.0 \mathrm{~g}$ は $856,1.6 \mathrm{~g}$ は 671 と低下した（図 4)。一方昇压群では $0.4 \mathrm{~g}$, $1.0 \mathrm{~g}$ および1.6gの腫昜の AUC はともに 1600 程度 と高値で一定し, したがって非昇圧群に対する昇 圧群の AUC の比は, $0.4 \mathrm{~g}$ の腫揚では 1.5 倍,

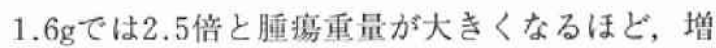
加率も大きくなった。

\section{4. 考察}

非昇圧下における腫瘍内 $5-\mathrm{FU} レ$ レルは, 腫 瘍重量と密接に相関 $(r=-0.95 \sim-0.39)$ する ことが明らかとなった。このことは制癌剤は腫瘍 の深部に到達しにくく，かつ大きい腫瘍ほど薬剂 の到達が少ないことを示唆するものと思われる。 胃癌, 乳癌, および大腸癌が進行すると 5 -FU 投与後の腫瘍内 $5-F U$ 濃度は減少すること Walker 256 担癌ラットに Mitomycin C を投与し 
Tumor weight (g)

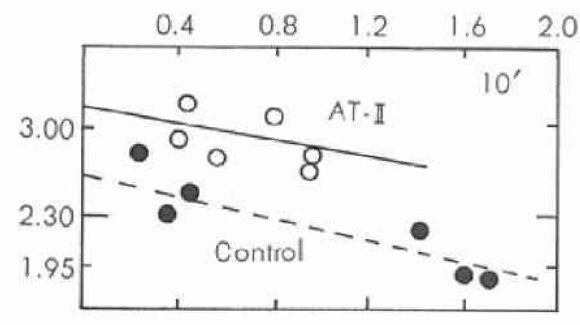

Control: $Y=2.880-0.586 X$

$$
r=-0.944
$$

AT. I : $Y=3.174-0.388 X$

$r=-0.488$

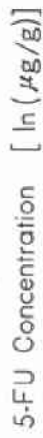
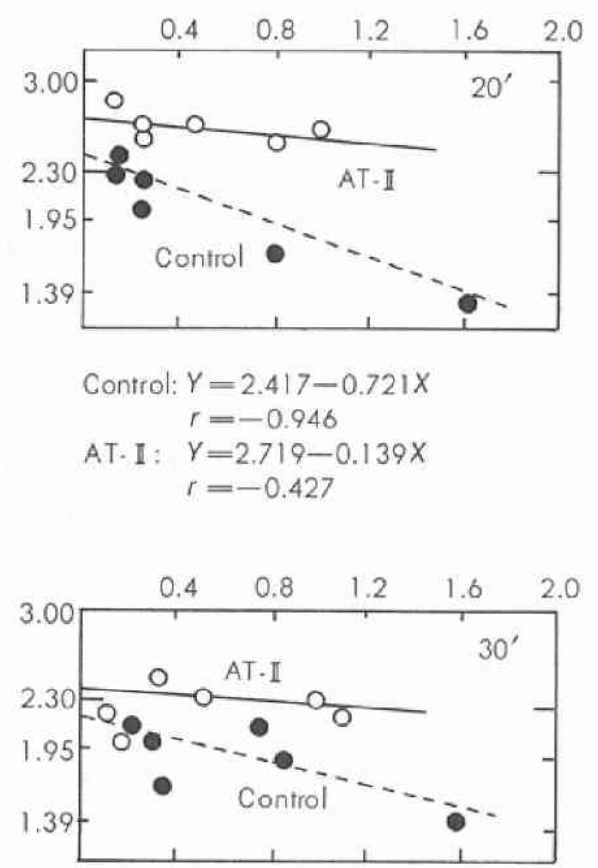

$$
\begin{array}{ll}
\text { Control: } & Y=2.088-0.292 X \\
& r=-0.552 \\
\text { AT. I } & Y=2.507-0.160 X \\
& r=-0.295
\end{array}
$$

Control: $Y=1.602-0.447 X$

$$
r=-0.386
$$

AT. I : $Y=2.194-0.183 X$ $r=-0.224$

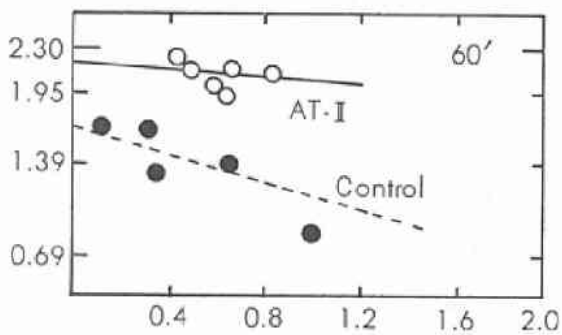

Control: $Y=1.319-0.333 X$

$$
r=-0.687
$$

AT. I : $\quad Y=1.457+0.198 X$ $r=0.341$

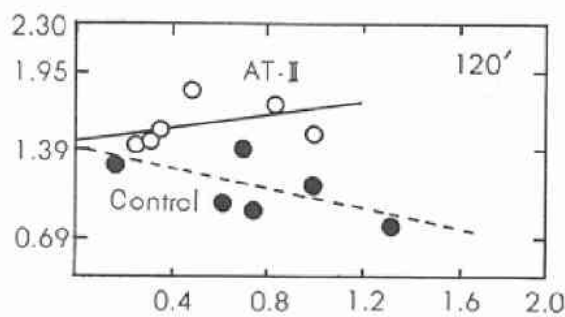

Control: $Y=1.193-0.302 X$

$$
r=-0.643
$$

AT. I : $\quad Y=0.977+0.419$ $r=0.17$

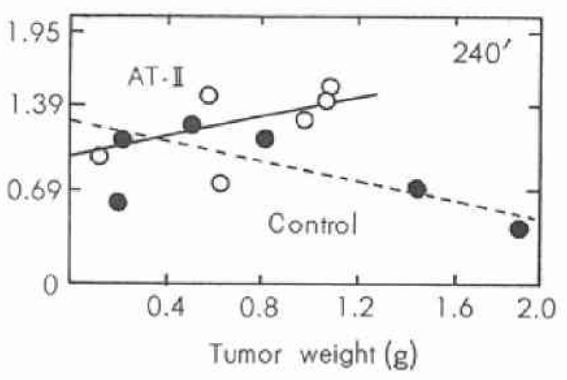

図 3 5-FU投与後の腫瘍組織内5-FU濃度と腫㾇重量との関係

たのち，大きい腫湯ほど Mitomycin Cレベルは低 下し，腫瘁重量と逆相関するこどなどがすでに 報告されており，制恝剂および腫痬の種類による 組織到達性の程度の差はあるものの, 制癌剤投与 後の腫瘍内薬荗濃度匂配は普遍的現象と捉えるこ
とができるものと思われる。

腫瘍組織内薬荗濃度を決定する因子は, 腫瘍血 管の分布密度のほか, 薬剂の血液から組織への移 行性が大きく関与すると思われる。薬剤の血液か ら組織への移行の程度を調べるために, in vitro 


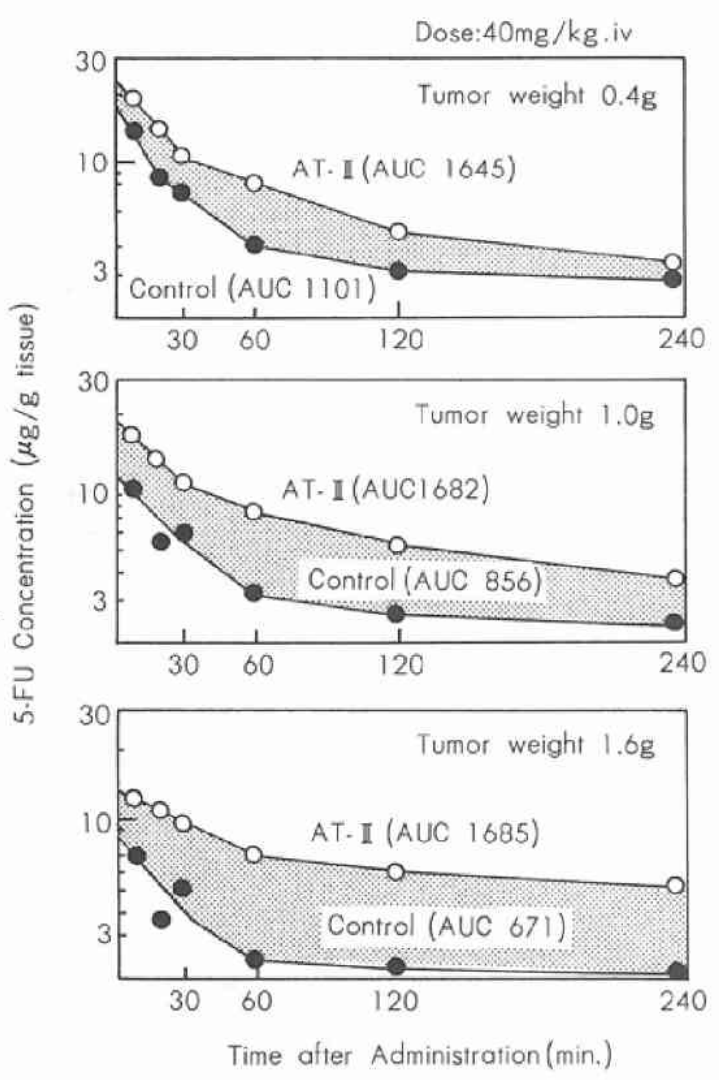

\section{図 4 腫瘍重量の变化による腫瘍組織内5-FUの $A \cup C(0-4 \mathrm{hr})$ の変化}

での実験モデルとして，“cellular spheroids”を 用いた実験がなされている。その結果，5-FU は celular spheroidsに速やかに浸透するのに対し adriamycin, methotrexate, vincristine では組織へ 浸透する速度はきわめて遅く, 制癌剤の種類によ り大きく異なることが報告されている ${ }^{8-109} 。$

一方, 藤田ら を移植し, Adriamycin, 5'-DFUR では腫瘍血管 の分布密度（vascularity）の大きい腫瘍ほど，大 きい制福効果が得られ，両者が相関することを報 告している。昇压により腫瘍組織の vascularity が大幅に増加することが知られているが，これら の制癌剤がIHCにおいて最も增強効果を示すの か興味あるところである。

阿部ら ${ }^{121}$ は, その総説で抗癌剛の response は 腫瘍の大きさに依存して変化することを報告して
おり,この現象を説明するメカニズムの可能性の ひとつとして, 腫瘍内組織圧が腫瘍の成長ととも に増加し，腫疼血管を压迫し，血流量を減少させ， 腫痹内に hypovascular areaを形成し,ひいては 腫瘍細胞と制癌凨の接触の機会を少なくさせるこ とが考えられる

今回, IHC 下の pharmacokinetics の研究では, 各種正常臓器における 5 -FU の AUC の有意な増 加はみられないが, 腫瘞組織において選択的に AUC が少なくとも1.6倍増加し, 腫瘍が大きいほ ど AUC の増加率も大きくなること, さらに腫瘍 深部への到達性がIHCにより改善され得ること が明らかとなった。

IHC 下では, 5 -FU の腫瘍組織への取り込み が多くなると同時に, 腫瘍組織からの wash out も多くなる。また,この IHC下の wash out の程 度は，腫瘍が小さいほど大きい。wash outをさ らに少なくすることができれば, より一層 IHC の効果を上げることが可能となるであろう。

以上のことを総合すると, IHC は腫瘍血管の特 異性を利用した独特の Drug delivery system と考 えられ, 今後の化学療法の效果改善に期待がもて るものと思われる。

\section{文献}

1) 鈴木磨郎, 佐藤春郎：制癌剂の癌組織到達性に 関する実験的研究. 癌と化学療法, 4 (1), 97 -102, (1977).

2) Suzuki. M., Hori, K., Abe, I. et al : A new approach to cancer chemotherapy, selective enhancement of tumor blood flow with angiotensin II . J. Natl. Cancer Inst., 67, 663 669, (1981).

3) 涌井昭，佐藤春彦：腫㿋血管の特性に基ついた 昇压化学療法. 癌と化学療法, 14 (3), 942 950, (1987).

4) 佐藤春彦, 星正颜, 涌井昭：昇圧化学療法によ る癌の郘床. 癌と化学療法, 13(4), 1439 1447, (1986).

5) 藤田浩：制癌郕の体内分布. 癌と化学潦法, 1 (3), 497 503,(1974).

6）江崎柳節：抗㾔郕の組織到達性と線溶凝固因子. 癌と化学療法, 4 (1)，103－107,(1977). 
7) 佐藤忠比古：動注化学瘄法における腫瘜内藻㝄 到達量基碳実験．癌と化学療法，12(9)，1883 $\sim 1884$. (1985).

8) West, G. M., Weichselbaum, R. and Little, J. B. : Limited penetration of methotrexate into human osteosarcoma spheroids as a proposed model for solid tumor resistance to adjuvant chemotherapy. Cancer Res., 40, 3665 3668, (1980).

9) Nederman, T. and Carlsson, J. : Penetration and binding of vinblastine and 5 -fluorouracil in cellular spheroids. Cancer Chemother. Pharmacol., 13. 131 135, (1984).

10) Kerr, D. J. and Kaye, S. B. : Aspects of cytotoxic drug penetration. with particular reference to anthracyclines. Cancer Chemother. Pharmacol., 19, $1 \sim 5,(1987)$.

11）藤田史子，藤田昌英，木本安彦ほか：ヒト癌 ヌードマウス移植株の徽細血管構築と抗癌剤感 受性. 癌と化学療法, 12(8), 1618 1624, (1985)

12) Abe, I., Suzuki. M., Hori., K. et al : Some aspects of size dependent differential drug response in primary and metastatic tumors. Cancer and Meta. Rev., 4, 27 40, (1985).

13) Hori, K., Sato, M., Abe, I. et al : Increased tumor tissue pressure in association with the growth of rat tumors. Jap. J. Cancer Res. (Gann), 77, 65 73, (1986). 